\title{
Loss of beta1 integrin function results in upregulation of connexin expression in embryonic stem cell-derived cardiomyocytes
}

\author{
JAROSLAW CZYZ ${ }^{1}$, KAOMEI GUAN ${ }^{2}$, OINGHUA ZENG ${ }^{3}$ and ANNA M. WOBUS* \\ ${ }^{1}$ Department of Cell Biology, Faculty of Biotechnology, Jagiellonian University, Cracow, Poland, ${ }^{2}$ Department of Cardiology and Pneumol- \\ ogy, Georg-August University of Göttingen, Göttingen, Germany and ${ }^{3}$ Institute of Genetics and Cytology, Northeast Normal University, \\ Changchun, China
}

\begin{abstract}
We show that loss of $\beta 1$ integrin function affects connexin (Cx) expression in embryonic stem (ES) cell-derived cardiomyocytes. Both loss of $\beta 1$ integrin function and inhibition of integrin clustering by RGD peptides in wild type ES cells correlated with upregulated expression of gap junctional proteins in ES-derived cardiomyocytes. The upregulation of connexin transcript levels in $\beta 1$ integrin-deficient cells is paralleled by a higher fraction of cells co-expressing Cx40 and Cx43. These observations demonstrate that the expression of connexins in developing cardiomyocytes is correlated to integrin-dependent mechanisms. Further, we found that upregulated cardiac connexin expression in $\beta 1$ integrin-deficient cells is related to Rho- and Wnt-dependent pathways. $\beta 1$ integrin-deficient cardiac cells displayed high levels of cytoplasmic $\gamma$ - and $\beta$-catenins throughout the differentiation period. The administration of lithium, an activator of $\beta$-catenin-dependent pathways, resulted in up-regulated connexin mRNA levels in wild type cardiomyocytes at intermediate, but not at early stages, indicating that the effects are restricted to advanced stages of cardiac differentiation. On the other hand, inhibition of Rho-dependent integrin signaling by treatment of cardiac cells with exoenzyme $\mathrm{C} 3$ resulted in immediate up-regulation of cardiac connexin transcript levels at early differentiation stages. Our data indicate that integrin function affects connexin expression in cardiomyocytes via direct effects on RhoA-dependent signaling mechanisms at early differentiation stages and of $\beta$-catenin/Wnt-dependent pathways at advanced stages.
\end{abstract}

KEY WORDS: $\beta 1$ integrin, connexin, $\beta$-catenin, cardiomyocyte, ES cell

\section{Introduction}

Gap junctional channels constituted by transmembrane proteins of the connexin (Cx) family (Gros and Jongsma, 1996) play an important role in the myocardium (Gros and Jongsma, 1996; van Veen et al., 2001) by synchronising the contractile activity of cardiomyocytes. The differential expression of three cardiac-specific connexins, $\mathrm{Cx} 40, \mathrm{C} \times 43$ and $\mathrm{C} \times 45$, in the heart muscle coordinates the propagation of contractile signals between highly specified myocardial regions (Kanter et al., 1993; Gros and Jongsma, 1996). Because $\mathrm{Cx} 40$ and $\mathrm{Cx} 43$ do not form functional heterotypic channels (Elfgang et al., 1995; Czyz et al., 2000), the diversity of connexin expression in the myocardium is an important mechanism to control excitation signal propagation and synchronization of cardiac action. In addition, gap junctions are important for the control of cardiac development. Disturbed connexin expression has been shown to correlate with pathophysiological disorders such as arrhythmias (Verheule et al., 1999), malformations of the right ventricle outflow tract (Reaume et al., 1995; Ya et al., 1998) or defective development of the cardiac vascular system (Kirchhoff et al., 2000).

The stabilization of the structure and function of cardiac tissue is further provided by cadherin-dependent intercalated discs (Forbes and Sperelakis, 1985) and cell-extracellular matrix interactions mediated by receptors of the integrin family (Ross and Borg, 2001). Intercalated discs composed of zonulae adherens and desmosomes are involved in the sequestration of $\beta$-catenin (Ben Ze'ev et

Abbreviations used in this paper:cx, connexin;EB, embryoid body; ES, embryonic stem; MLC, myosin light chain; RGD, arginine-glycine-aspartic acid tripeptide; RGE, arginine-glycine-glutamic acid tripeptide; TCF, T cell factor.

*Address correspondence to: Dr. Anna M. Wobus. In Vitro Differentiation Group, Institute of Plant Genetics and Crop Plant Research (IPK), Corrensstr. 3, 06466 Gatersleben, Germany. Fax: +49-39482-5481. e-mail: wobusam@ipk-gatersleben.de 
al., 2000) and the structural stabilization of gap junctional channels (Hertig et al., 1996). A remodelling of intercalated discs by deregulated expression of cadherins led to cardiomyopathy in mice (FerreiraCornwell et al., 2002). Moreover, activation of the canonical Wnt signalling pathway resulted in up-regulation of connexin expression in $\mathrm{P} 12$ cells (van der Heyden et al., 1998) and rat cardiomyocytes (Ai et al., 2000) suggesting a role of Wntdependent mechanisms in the establishment of intercellular coupling in the cardiac system. However, the role of signalling pathways determined by integrins in the regulation of cardiac connexin expression remained unknown.

Based on our previous data, which showed up-regulated Wnt-1 transcript levels in $\beta 1$ integrin-deficient ( $\beta 1-/-)$ cells (Rohwedel et al., 1998), we analyzed the expression of cardiac connexins in $\beta 1-/-$ and wild type (wt) embryonic stem (ES) cells. These studies showed a correlation between $\beta 1$ integrin deficiency and up-regulated transcript levels of cardiac connexins in ES-derived cardiomyocytes indicating that the expression of genes encoding cardiac connexins is negatively regulated by integrin-dependent mechanisms. Whereas, at early differentiation stages, this effect is most probably exerted via direct effects of RhoA-dependent signaling, $\beta$-catenin- and Wnt-dependent mechanisms regulate connexin expression at intermediate and late cardiac differentiation stages.

\section{Results}
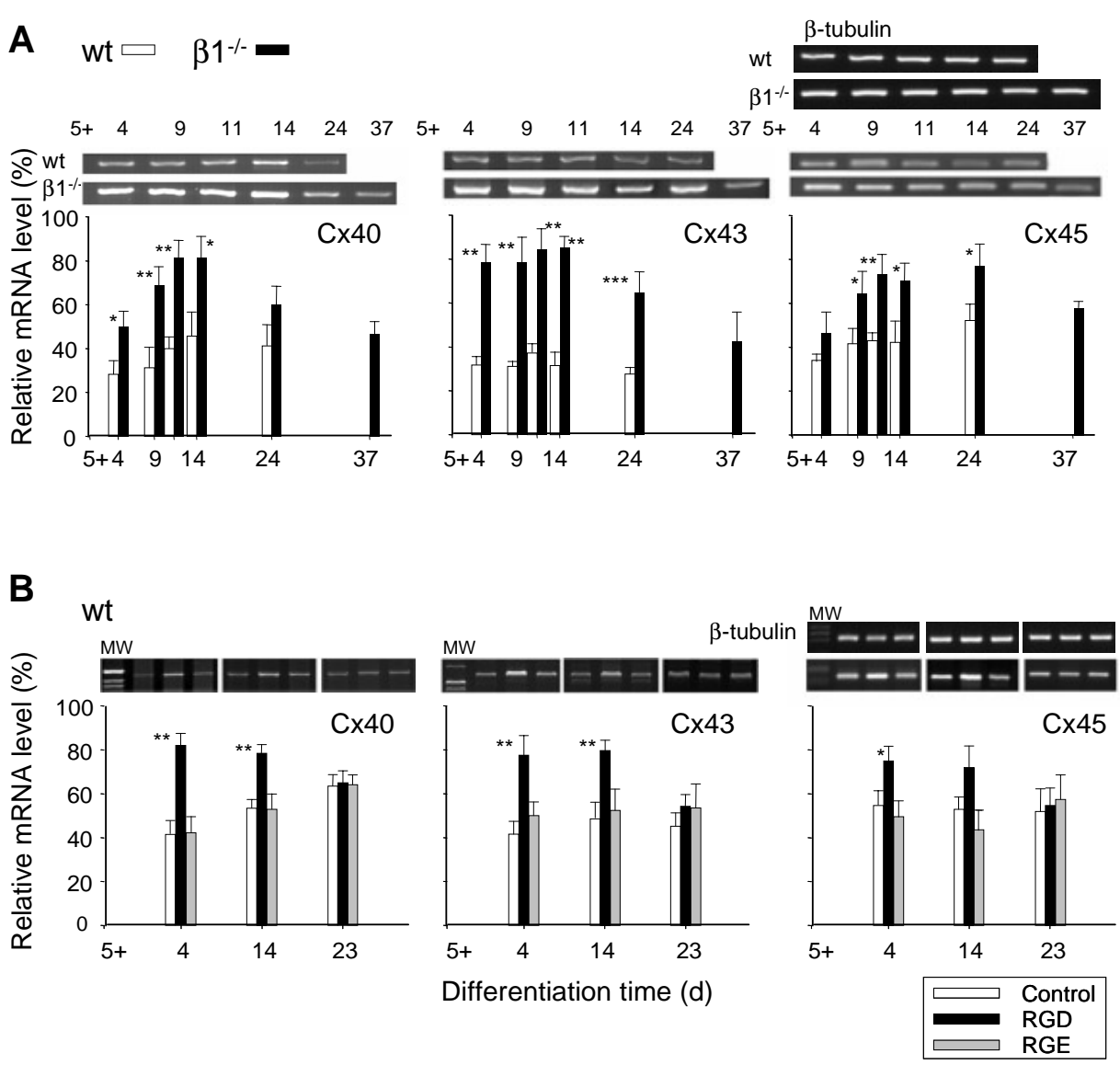

Fig. 1. RT-PCR analysis of $\mathrm{Cx40}, \mathrm{C} \times 43$ and $\mathrm{Cx} 45$ transcript levels in cardiac clusters isolated from wt and $\beta 1$-/-ES cell-derived outgrowths (A) and from wt cells treated with RGD peptides (B). Upregulated transcript levels of cardiac-specific connexins were observed in $\beta 1$ - - clusters compared to their wt counterparts. Similarly, the application of RGD peptides to wt cells during EB formation resulted in increased mRNA levels of all three cardiac-specific connexins at early $(5+4 d)$ and intermediate $(5+14 d)$, but not at late $(5+23 d$ d) differentiation stages. This effect was not observed upon administration of $R G E$ (inactive analogue) oligopeptides. Each value represents mean \pm SEM. $\beta$-tubulin was used as internal standard. Statistical significance was tested by the Student t-test: ${ }^{*}{ }^{*}<0.1 \%,{ }^{*}<1 \%,{ }^{*}<5 \%$.

RT-PCR analyses revealed significantly up-regulated Cx40, Cx43 and Cx45 mRNA levels in isolated cardiac clusters of $\beta 1-/$ - cells compared to wt cells (Fig. 1A). Whereas Cx43 transcript levels were up regulated in $\beta 1-/$ - cells at all differentiation stages, Cx40 mRNA levels were elevated at early and intermediate and Cx45 levels were increased at intermediate and terminal stages. The results indicate a negative regulatory function of $\beta 1$ integrin signalling on the expression of cardiac-specific connexins in cardiomyocytes.

The involvement of $\beta 1$ integrins in the regulation of connexin expression in ES-derived cardiomyocytes was confirmed by the inhibition of integrin clustering by soluble RGD sequence-containing oligopeptides in wt cardiomyocytes (Hynes, 1992). Treatment of differentiating cardiac cells with RGD peptides during EB formation (between day 0 and 5) induced a significant up-regulation of transcript levels of cardiac-specific connexins in wt cardiac cells at early (5+4 d; Cx40, Cx43, Cx45) and intermediate (5+14 d; Cx40, Cx43) stages (Fig. 1B), whereas the inactive (RGE) fibronectin analogue exerted no effect on connexin expression.
The correlation between loss of $\beta 1$ integrin function and increased cardiac connexin levels was further analysed by immunofluorescence assays of $\mathrm{Cx} 40$ and $\mathrm{Cx} 43$ in ES cell-derived cardiac clusters (Fig. 2). Higher fraction of cardiac clusters characterized by the presence of connexins at cell-to-cell contacts was observed in $\beta 1-/$ - cell populations at early $(5+6 \mathrm{~d})$ and intermediate $(5+14 \mathrm{~d})$ differentiation stages compared to wt cells. This effect was paralleled by an increased fraction of clusters expressing both $\mathrm{Cx} 40$ and $\mathrm{Cx} 43$ connexins in $\beta 1-/-$ cells. More than $50 \%$ of cells showed $\mathrm{Cx} 40$ and $\mathrm{C} \times 43$ co-expression in $\beta 1-1$ - compared to $20 \%$ in wt cardiomyocytes (Fig. 2A,B). Moreover, co-localization of $\mathrm{C} \times 40$ and $\mathrm{C} \times 43$ in cell-to-cell contacts was frequently observed in $\beta 1$-/- cardiac clusters (Fig. 2D), whereas in wt populations $\mathrm{Cx} 40$ and $\mathrm{Cx} 43$ generally occupied discrete regions of the clusters (Fig. 2C).

Several studies demonstrated $\mathrm{C} \times 43$ as a target of the canonical Wnt signaling pathway (van der Heyden et al., 1998, Ai et al., 2000) and a correlation between cytoplasmic accumulation of $\beta$-catenin and connexin expression. Moreover, $\gamma$-catenin was shown to form 
complexes with Wnt-responsive transcription factors (Maeda etal., 2004). Therefore, we analyzed how the loss of $\beta 1$ integrin function influenced the intracellular localization of $\gamma$-catenin and $\beta$-catenin in developing cardiac cells. Cadherins were present at intercalated disc-like structures in $\beta 1-/-$ and wt cardiac clusters, but showed disorganized structures in $\beta 1$-/- cells (Fig. 3E cf. B). Disorganization of intercalated disc-like structures in $\beta 1-/-$ cells correlated, however, with more intensive cytoplasmic staining of $\gamma$-catenin (Fig. 3A cf. D). Similarly, considerably higher cytoplasmic $\beta$-catenin levels in $\beta 1-/-$ cardiac cells at all stages throughout the differentiation period were detected by immunofluorescence analysis (Fig. 4A-F) and immunoblotting (Fig. 4G). Although, no detectable nuclear accumulation of $\gamma$-catenin and $\beta$-catenin was observed, a certain threshold concentration of these proteins in the nuclei of $\beta 1-/$ - cardiac cells can be reached due to the increase in the overall amount of both catenins. This effect could result in the activation of Wnt-dependent signalling pathways in differentiating $\beta 1-/$ - cardiac cells.

The correlation between $\beta$-catenin signalling and connexin expression in developing cardiomyocytes was confirmed by RT-PCR analyses of connexins in lithium-treated cardiomyocytes. Cardiomyocytes were treated with lithium, known to activate Wnt-1- and $\beta$ catenin-dependent signalling pathways between days 5 and $5+37$. Lithium induced a dose-dependent upregulation of $\mathrm{Cx} 40$ and $\mathrm{Cx} 45$ mRNA levels especially at intermediate ( $\mathrm{C} \times 40$ and $\mathrm{C} \times 45$, see Fig. D, E) differentiation stages (when connexin transcript levels were estimated relative to cardiac ventricle-specific MLC-2v mRNA levels). On the other hand, effects of lithium on $\mathrm{Cx} 40$ and $\mathrm{Cx} 45$ expression in $\beta 1$ /- cells were not detectable (Fig. $5 \mathrm{~F}, \mathrm{G}$ ).

To further analyse the involvement of Wnt-1-dependent pathways in the regulation of cardiac connexin expression, we determined the intracellular localization of TCF-4, a key transcription factor involved in Wnt-1 signalling (Barker et al., 2000). Immunofluorescence studies revealed the nuclear accumulation of TCF-4 in $\beta 1-/$ - cardiomyocytes at day $5+14$, whereas, in wt cells this effect was observed only at day $5+24$ (Fig. 6).

Furthermore, we analysed the effect of lithium on intracellular localization of TCF- 4 at day $5+14$, when the highest effect of lithium on cardiac connexin expression in wt cells was observed. Lithium treatment induced nuclear accumulation of TCF-4 (Fig. 7C cf. 7A). These findings confirm the accelerated activation of the Wnt canonical pathway in $\beta 1$-/- cells compared to wt cells which correlates with the accelerated expression of Wnt- 1 in $\beta 1$-/- cells (Rohwedel et al., 1998) and its role in the regulation of cardiac connexin expression. However, despite high $\beta$-catenin levels, no nuclear accumulation of TCF- 4 was observed in $\beta 1-/$ - cells at early stages indicating that the $\beta$-catenin-dependent signaling pathway may not be
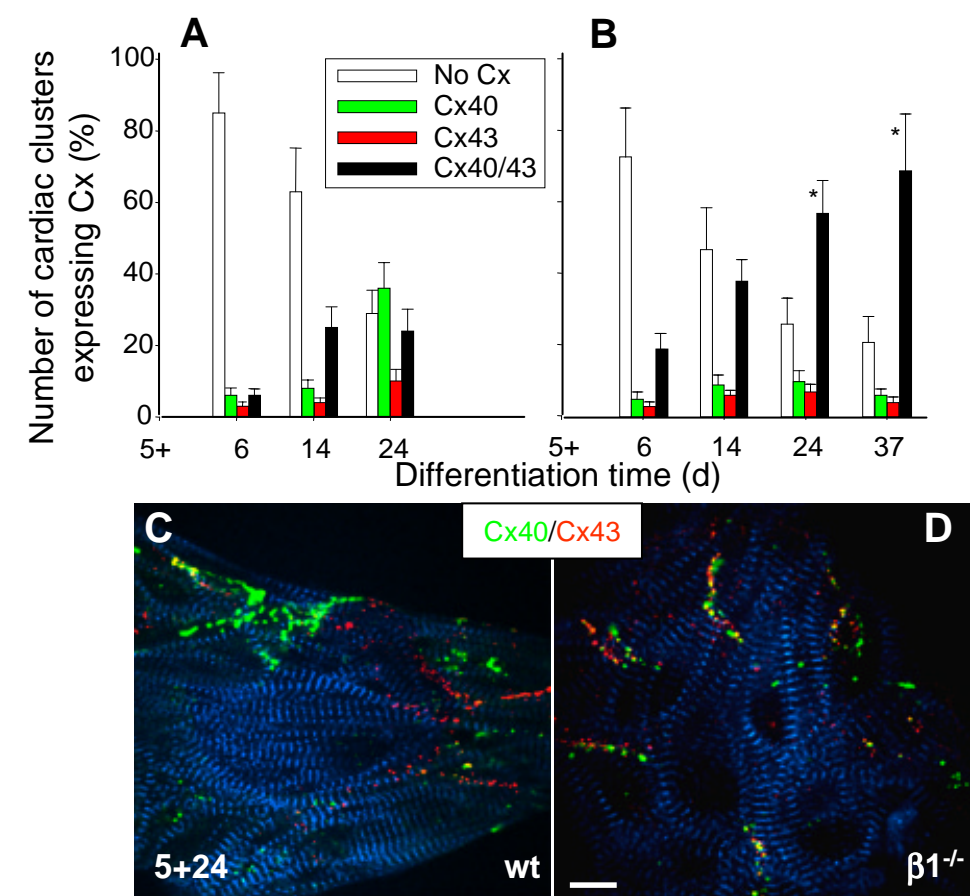

Fig. 2. Expression pattern of $\mathrm{Cx} 40$ and $\mathrm{Cx} 43$ in wt and $\beta 1-/-$ cardiac clusters analysed by immunofluorescence. The number of cardiac clusters characterized by the presence of connexins at cell-to-cell contacts was higher in $\beta 1-/-(\mathbf{B})$ compared to wt (A) cells at early $(5+6 d)$ and intermediate $(5+14 d)$ differentiation stages. This effect was paralleled by increased numbers of clusters characterized by co-expression of both connexins in $\beta 1-/$ - cell populations (B). (C) represents a wt cluster expressing $C \times 40$ and $C \times 43$ in discrete regions. Moreover, $\beta 1-/$ - cardiac clusters show co-localization of $C \times 40$ and $C \times 43$ at individual cell-to-cell borders (D). Each value represents mean \pm SEM. Statistical significance was tested by the Student t-test: ${ }^{*}<5 \%$. Bar, $10 \mu \mathrm{m}$.
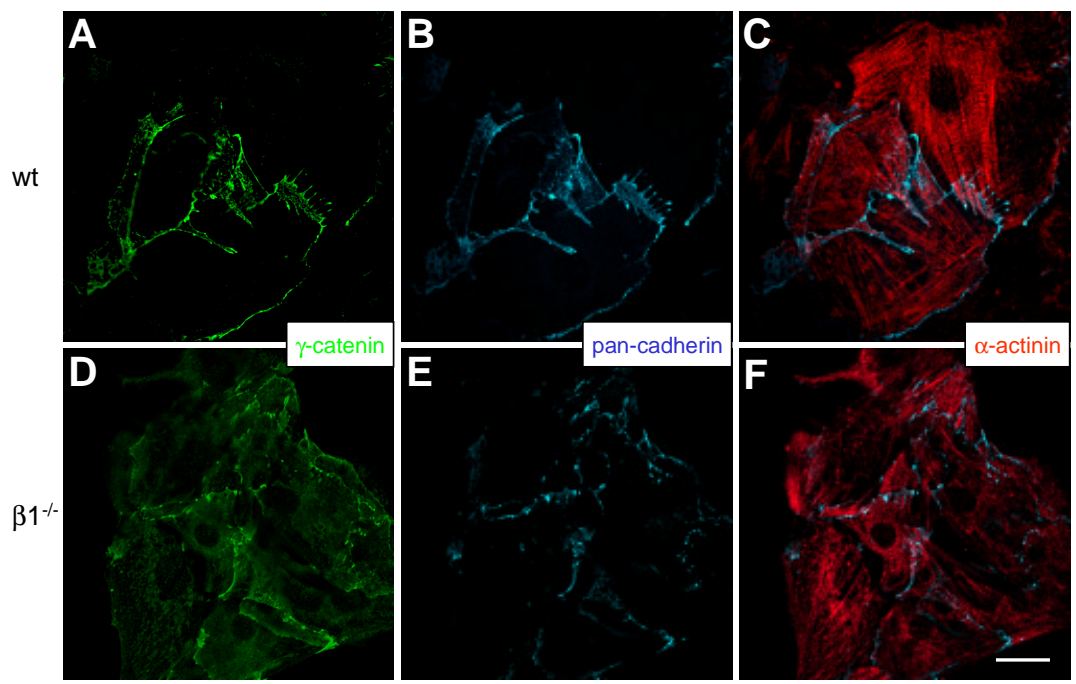

Fig. 3. Triple immunofluorescence analysis of $\gamma$-catenin (green) and pan-cadherin (blue) in wt (A-C) and $\boldsymbol{\beta} 1-/-$ (D-F) ES-derived isolated cardiac clusters. Both proteins displayed high degrees of co-localization at cell-to-cell borders in wt cells (A,B), whereas the cadherin-mediated intercellular contacts were disturbed in $\beta 1-/-c e l l s ~(E, c f . B)$ and increased cytoplasmic staining of $\gamma$-catenin was found in $\beta 1-/-$ cells (D, cf. A). (C,F) represent merges of pan-cadherin (blue) and $\alpha$-actinin (red) staining used to identify cardiac clusters. Bar, $20 \mu \mathrm{m}$. 


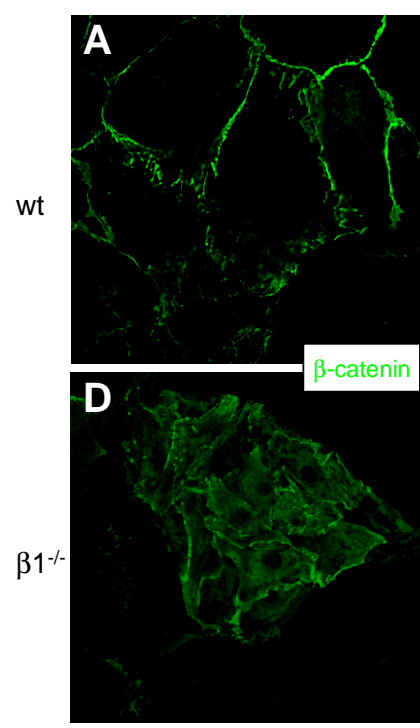

G

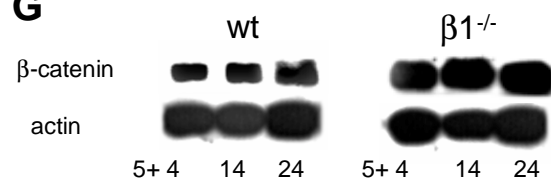

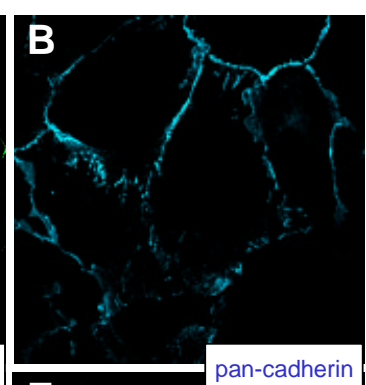
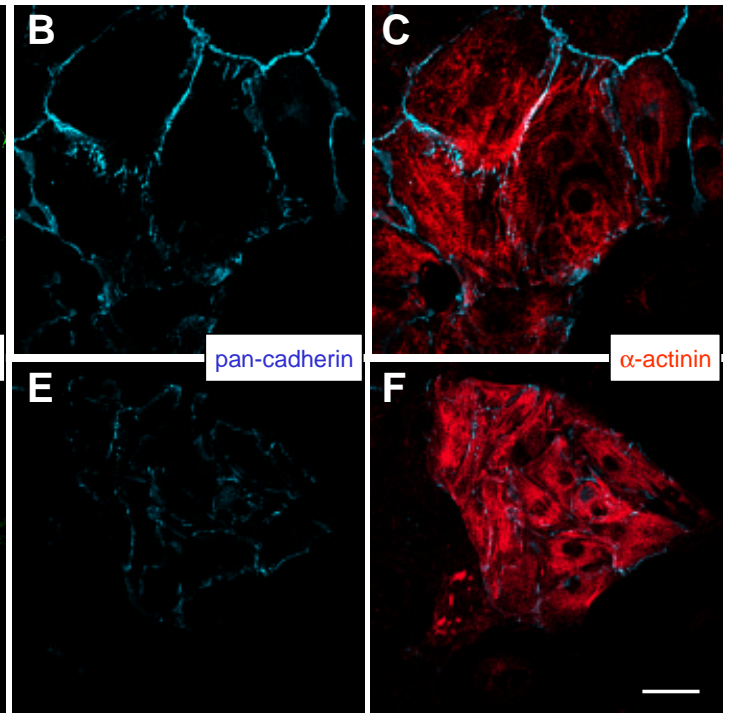

Fig. 4. Comparison of the intracellular distribution and co-localization of $\beta$ catenin (green) and pan-cadherin (blue) in isolated clusters of wt (A-C) and $\boldsymbol{\beta} \mathbf{1}-/$ - (D-F) cardiomyocytes. $A$ down-regulation of cadherin-mediated intercellular contacts in $\beta 1$ - - cells (E) compared to wt cells (B) was found. Immunofluorescence showed diminished levels of co-localization of both proteins in $\beta 1-/-c e l l s(D, E, c f . A, B$ for wt cells) paralleled by increased cytoplasmic levels of $\beta$-catenin in $\beta 1-/-c e l l s$ in differentiating ES cells at day $5+4,5+14$ and $5+24$ (G). (C,F) represent merges of pan-cadherin (blue) and $\alpha$-actinin (red) staining used to identify cardiac clusters. Bar, $20 \mu \mathrm{m}$.

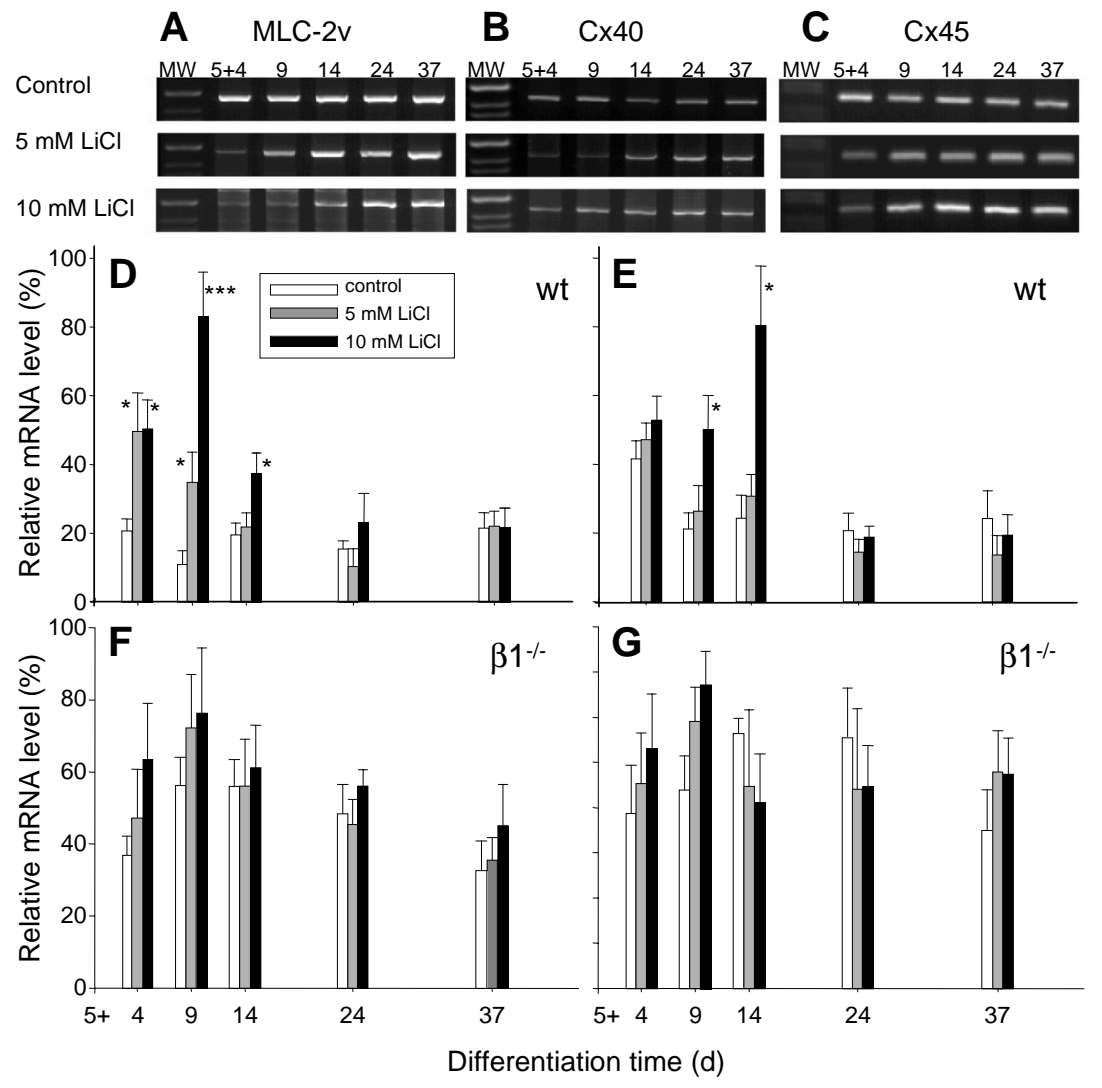

responsible for the early induction of connexin expression in these cells.

To study alternative pathways that may be involved in the up-regulation of cardiac connexin expression in $\beta 1$ integrin-deficient cells at early stages of cardiac differentiation, we analysed RhoA-dependent mechanisms in wt ES cells. RhoA has been shown to induce acute loss of intercellular communication (Postma etal., 1998). ES-derived wt cells were treated at day $5+4$ with Clostridium botulinum exoenzyme C3 (ExoC3), an inhibitor of RhoA. As shown in Fig. 8A, treatment of ES cells by ExoC3 for $10 \mathrm{~h}$ resulted in a significant upregulation of Cx40, Cx43 and Cx45 transcript levels in isolated cardiac clusters immediately (3h) after incubation, whereas $6 \mathrm{~h}$ treatment had no effects on connexin transcript levels. No effect of ExoC3 was observed $16 \mathrm{~h}$ after incubation suggesting an immediate effect of RhoA-dependent pathways on connexin expression. Similarly, ExoC3 exerted no effect on connexin transcript levels in $\beta 1 /-$ cardiomyocytes (Fig. 8B). In summary, our results suggest that at early differentiation stages, connexin expression in cardiomyocytes is regulated via integrin- and Rho-mediated pathways.

\section{Discussion}

Whereas the role of gap junctional coupling in the coordination of synchronized activity of the myocardium is established, mechanisms that regulate cardiac connexin expression at early stages of cardiac differentiation are largely unknown. Using $\beta 1$ integrin-deficient ES-derived cardiomyocytes, we show a correlation between impaired expression of $\beta 1$ integrin and up-regulated levels of cardiac connexins. This correlation depends on the activity of Rho-dependent signalling pathways at early stages of differentiation, followed by $\beta$-catenin dependent mechanisms at intermediate and late stages.

Fig. 5. Effects of lithium on Cx40 (B) and Cx45 (C) expression in differentiating ES cells. EBS were cultivated in the presence of lithium between day 5 and 5+37 [5 mM (grey), $10 \mathrm{mM}$ (black), control (white)] and $C \times 40$ and $C x 45$ levels were analysed by $R T-P C R$ in relation to the cardiac-specific gene MLC$2 v$ (A). Lithium induced a dose-dependent up-regulation of $C \times 40$ (D) and $C \times 45$ (E) transcript levels in wt cells predominantly at intermediate stages, whereas only a slight induction of connexin expression was observed in $\beta 1-\%$ cells $(\mathbf{F}, \mathbf{G})$. Each value represents mean \pm SEM. Statistical significance was tested by the Student t-test: ${ }^{*} *<0.1 \%,{ }^{*}<1 \%,{ }^{*}<5 \%$. 

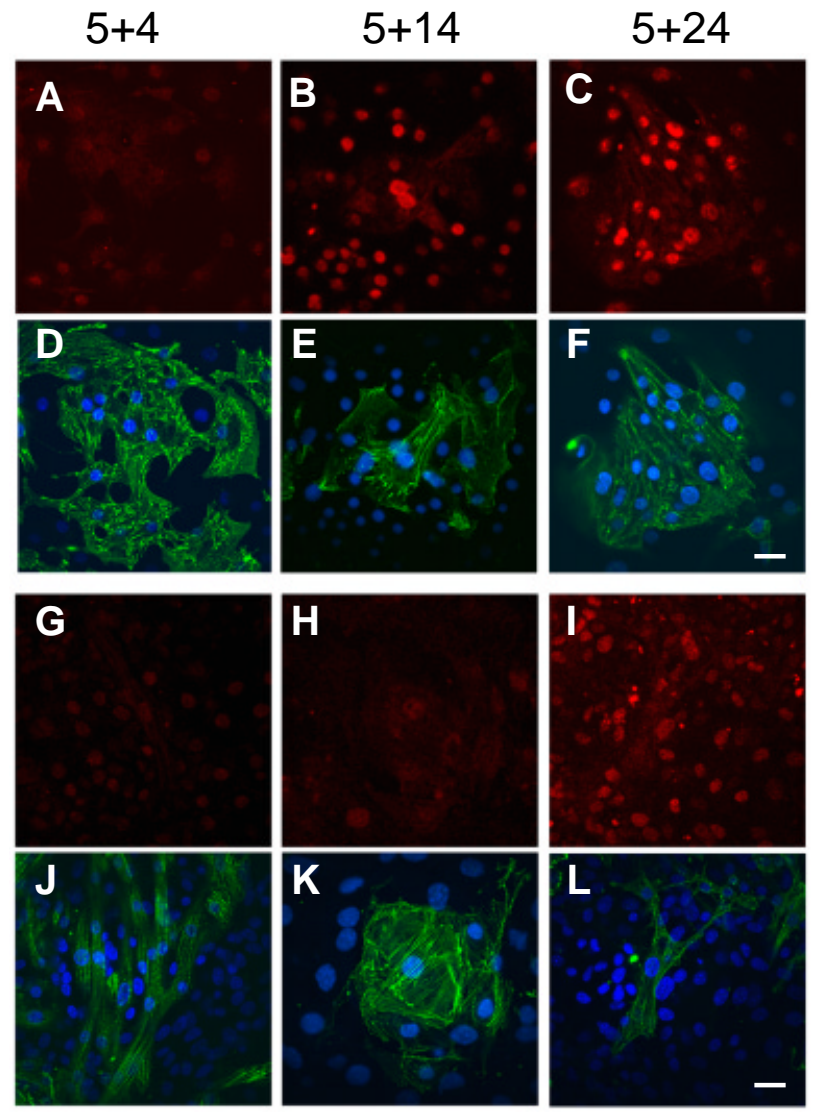

M

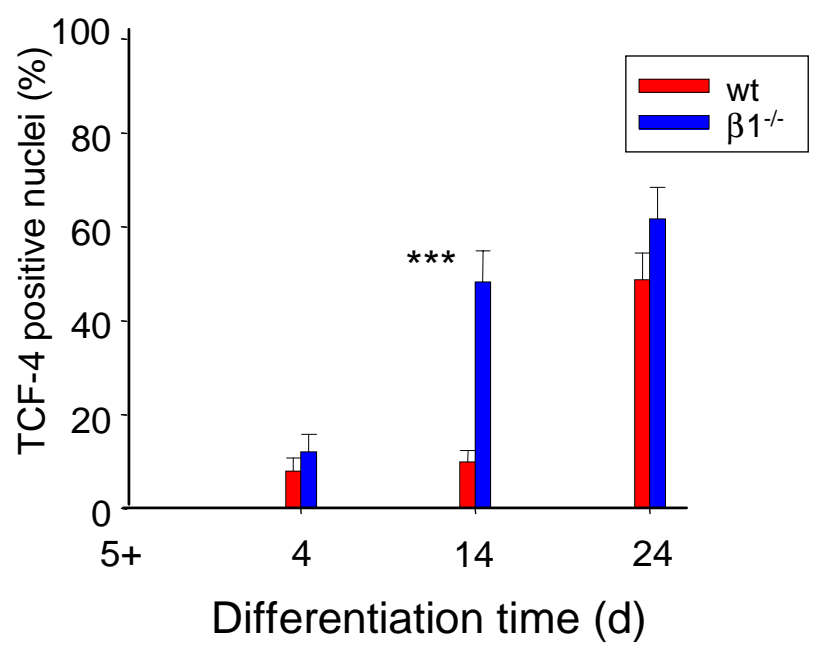

Fig. 6. Immunofluorescence analysis of intracellular localization of TCF-4, a Wnt-1 responsive transcription factor. (A-M) Nuclear translocation of TCF-4 was accelerated in $\beta 1-/-$ cells (A-F) compared to wt cells (G-L). $\beta 1$-/-cells (A-F) displayed a higher fraction of nuclei positive for TCF4 than their wild type counterparts (G-L) at intermediate differentiation stages $(5+14$ days, compare $B$ and $H$, quantitatively summarised in $M)$. Red, TCF-4; green, $\alpha$-actinin; blue, Hoechst 33342. Each value represents mean \pm SEM. Statistical significance was tested by the Student $t$-test: ${ }^{* * *}$ $<0.1 \%$. Bar, $20 \mu \mathrm{m}$.
Loss of $\beta 1$ integrin function correlated with up-regulated expression of genes encoding gap junctional proteins in ES-derived $\mathrm{B1}^{-/-}$cardiac cells; and this was paralleled by increased abundance of cardiac clusters expressing connexins in $\beta 1-/$ - populations. The functional correlation between integrin function and connexin expression was further substantiated by experiments with RGD oligopeptides, which demonstrated that the inhibition of integrin clustering affected transcript levels of genes encoding cardiac connexins. Partial differences in $\mathrm{Cx} 40$ and $\mathrm{C} \times 43$ expression patterns between $\beta 1$-/- populations and RGD-treated wt cells seem to result from a depletion or de-activation of RGD oligopeptides. This would reduce the increased level of connexins at later differentiation stages. However, it is also conceivable that, apart from $\beta 1$ integrins other RGD-dependent integrins may be involved in the regulation of, at least, $\mathrm{C} \times 40$. Moreover, co-localization of $\mathrm{C} \times 40$ and Cx43 in cell-to-cell contacts was frequently observed in $\beta 1$-/cardiac clusters, whereas in wt populations $\mathrm{C} \times 40$ and $\mathrm{C} \times 43$ generally occupied discrete regions of the clusters. Because $\mathrm{C} \times 40$ and Cx43 are co-localized in adult atria, Purkinje fibers and nodes (Gros and Jongsma, 1996), our present data would confirm earlier findings that showed an impaired differentiation of $\beta 1-/$ - cardiac cells into ventricle-like cardiomyocytes [which mainly express Cx43 (Fässler et al., 1998)].

We further concentrated on the mechanisms responsible for the observed correlation between the loss of integrin function and connexin expression in developing cardiomyocytes. One signalling pathway potentially involved in the observed phenomena is the Wnt canonical pathway, which was shown to regulate $\mathrm{C} \times 43$ expression in PC12 cells (van der Heyden et al., 1998) and rat
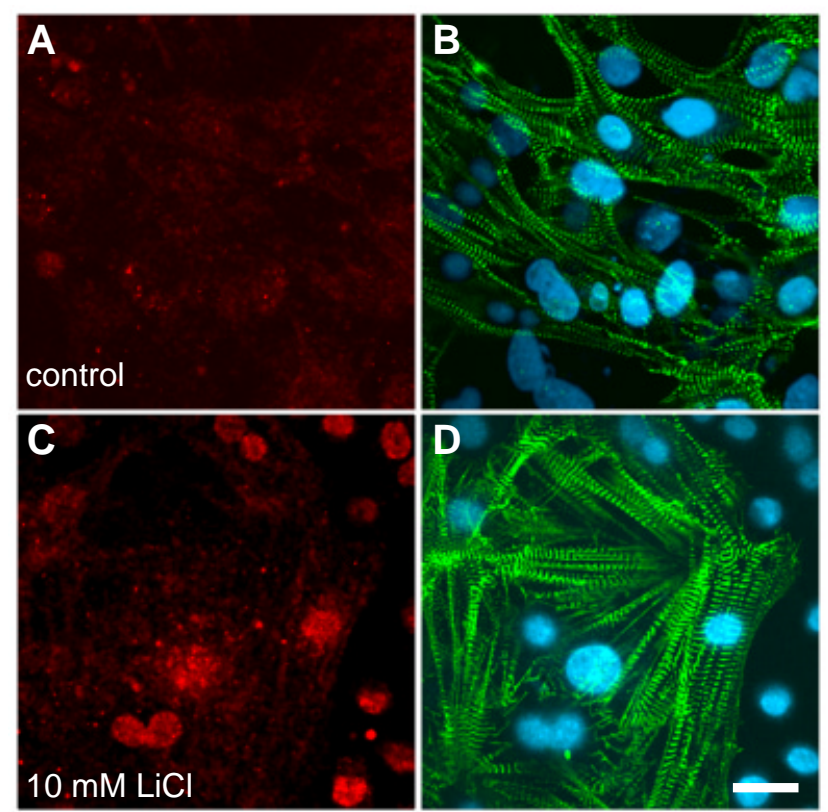

Fig. 7. Analysis of the intracellular localization of TCF-4 in wt cells cultured under control conditions $(A, B)$ and in the presence of $10 \mathrm{mM}$ LiCl (C, D). Cells were stained for TCF-4 (red) at day $5+14$ when the highest effect of lithium on cardiac connexin expression was observed (cf. Fig. 5). Lithium treatment induced nuclear accumulation of TCF-4 (C, cf. A). (B,D) represent merges of titin (green) and Hoechst 33342 (b/ue) staining used to identify cardiac clusters and nuclei. Bar, $20 \mu \mathrm{m}$. 

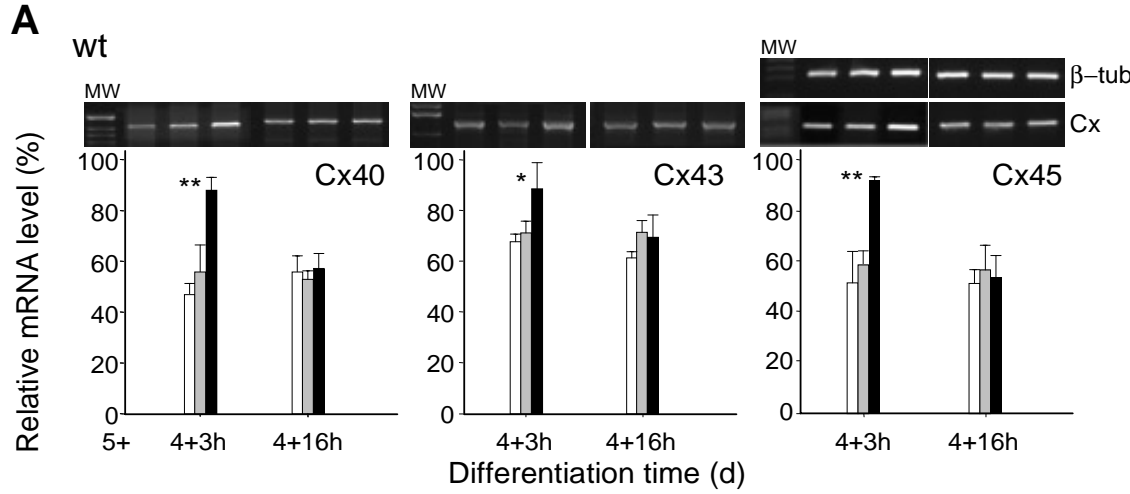

B
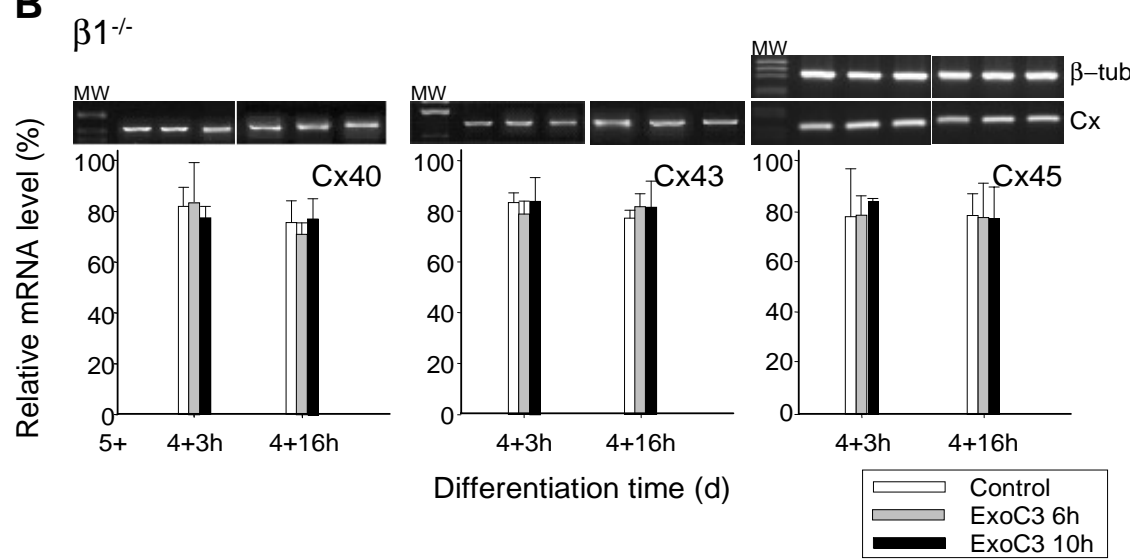

Fig. 8. Effects of ExoC3 on $\mathrm{Cx} 40, \mathrm{C} \times 43$ and $\mathrm{Cx} 45$ transcript levels in differentiating cardiac cells analysed by RT-PCR. (A) Incubation of wt ES-derived cells in the presence of $10 \mu \mathrm{g} / \mathrm{ml}$ of ExoC3 for $10 \mathrm{~h}$ (black bars), but not for $6 \mathrm{~h}$ (grey bars) resulted in a transient induction of connexin mRNA levels compared to control (open bars) when analysed $3 \mathrm{~h}$ after incubation. No effect was observed $16 \mathrm{~h}$ after incubation. (B) Similarly, ExoC3 exerted no effect on cardiac connexin mRNA levels in $\beta 1-/$-cells. Each value represents mean \pm SEM. Statistical significance was tested by the Student t-test: ${ }^{*}<1 \%,{ }^{*}<5 \%$.

cardiomyocytes (Ai et al., 2000). We found considerably higher cytoplasmic staining of $\gamma$-catenin and $\beta$-catenin and increased levels of soluble fraction of $\beta$-catenin in $\beta 1-/$ - cardiac cells at all stages throughout differentiation. This was paralleled by a disturbed organization of intercalated disc-like structures in $\beta 1$-/-cells.

$\beta$-catenin is an essential component of adhesion complexes, where it binds to the intracellular domain of cadherins thus connecting the actin cytoskeleton (Ben Ze'ev et al., 2000). In its cytoplasmic (soluble) form, $\beta$-catenin forms complexes with transcription factors of the Lef and TCF family, which activate the expression of target genes. Moreover, $\gamma$-catenin was shown to form complexes with Wnt-responsive transcription factors (Maeda et al., 2004). Wnt signalling leads to cytoplasmic accumulation of $\beta$-catenin (Wodarz and Nusse, 1998). Upregulated Wnt-1 transcript levels were observed in $\beta 1$-/- cells (Rohwedel et al., 1998), which can be reponsible for the activation of this pathway. Apart from Wnt signalling, the abundance of cytoplasmic $\beta$-catenin depends on the structure of cadherin-dependent intercalated discs, which are involved in the sequestration of catenin (Ben Ze'ev et al., 2000) and stabilization of gap junctional channels (Hertig et al., 1996). Co-localization of $\beta$-catenin and $\gamma$-catenin with pan- cadherins demonstrates the role of cadherinmediated intercellular contacts in the sequestration of catenins. Therefore, impaired cellsubstratum and cell-to-cell adhesion observed in $\beta 1-/-$ cell populations which results in cell shape changes (Guan et al., 2001) and disturbance of intercalated disc-like structures can release sequestrated $\beta$-catenin and $\gamma$-catenin, thus further strengthening cardiac cell responsiveness to Wnt signaling. It is conceivable that, due to increased levels of catenins, their nuclear fraction may reach a threshold value enabling them to trigger Wnt-responsive gene expression, without a specific accumulation of both catenins in cardiac cell nuclei. $\gamma$-catenin, which has recently been shown to interact with Wnt-responsive effectors (Maeda etal., 2004), could also participate in this effect. This hypothesis is supported by the observation of accelerated nuclear accumulation of TCF- 4 in $\beta 1$-/- cells. A functional correlation between $\beta$ catenin-dependent mechanisms and connexin expression was substantiated by the up-regulation of cardiac connexins in wt cells induced by the treatment with lithium, an external GSK$3 \beta$ inhibitor (Stambolic et al., 1996). The connexin up-regulation was observed in wt cardiomyocytes predominantly at intermediate differentiation stages. Moreover, lithium induced nuclear accumulation of TCF-4 in wt cells at an intermediate differentiation stage, when maximal effects of lithium on cardiac connexin expression were observed. It suggests that $\beta$-catenin-dependent signalling is involved in the regulation of cardiac connexin expression in ES-derived cardiomyocytes at intermediate stages, but can hardly account for the up-regulation of cardiac connexin levels in $\beta 1$-/- cells throughout the whole differentiation period.

The lack of lithium effects at late stages may result from "saturating" effects of Wnt-1 on a $\beta$-catenin-dependent canonical pathway (Rohwedel et al., 1998). Actually, at least the cytoplasmic fraction of $\beta$-catenin in wt cells is increased during differentiation and the effect of lithium on connexin expression levels in $\beta 1-/$ - cells is considerably lower than in wt cells. On the other hand, we cannot rule out the possibility that cardiac cells at early differentiation stages are less reactive to Wnt signalling, for instance, due to the impaired nuclear translocation of $\beta$ - or $\gamma$-catenin-reactive transcription factors.

This hypothesis was confirmed by the analysis of the intracellular localization of TCF-4, one of the key effectors of $\beta$-catenin. Nuclear accumulation of TCF-4, although accelerated in $\beta 1-/-$ cardiomyocytes, was not observed at early differentiation stages in spite of high amounts of cytoplasmic $\beta$-catenin in $\beta 1-/$ - cells. This would suggest that $\gamma$ - and $\beta$-catenin-dependent pathways, being involved in the regulation of cardiac connexin expression at intermediate and terminal ES cell differentiation stages, are less crucial for the up-regulation of connexin transcripts at early stages. 
Alternative pathways that may be involved in the upregulation of cardiac connexins in $\beta 1-/$ - cardiomyocytes may be directly regulated by integrin function. Such modulation has been shown for the integrin-linked kinase (ILK), which releases $\beta$-catenin to cytoplasm and induces its nuclear translocation (Novak et al., 1998). Similarly, another integrin effector, IQGAP1 takes part in the dissociation of $\alpha$-catenin from $\beta$-catenin thus inhibiting cadherinmediated cell-to-cell adhesion and, in consequence, increasing the cytoplasmic pool of $\beta$-catenin (Fukata et al., 1999). The activation of $G$ proteins resulted in the inhibition of connexin expression (Postma et al., 1998). We demonstrate that the inhibition of RhoA signalling resulted in up-regulation of connexin expression in wt cardiac cells, which, however, was transient, probably due to the connexin mRNAs turnover. Rho GTPase family proteins control a wide variety of cellular processes including cell differentiation (Van Aelst and D'Souza-Schorey, 1997). Inhibition of Rho family GTPases resulted in the disruption of cardiac morphogenesis (Wei et al., 2002). Therefore, the inhibition of Rho-mediated integrin signalling in ES-derived cardiomyocytes may explain the up-regulation of connexin expression observed at early stages of differentiation. Such synergistic interplay between separate signalling pathways dependent on Wnt and CAMP during the regulation of $\mathrm{C} \times 43$ expression has already been described for PC12 cells (van der Heyden et al., 1998). Altogether, our data suggest a correlation between factors determining structural integrity (cadherins and catenins) and conductivity (connexins) in early developing myocardial cells. The results present evidence for the interaction of integrin function and connexin expression, however questions arise about the biological significance of this correlation. The most straightforward explanation would assume that up regulated connexin levels are directly connected to the impaired terminal differentiation of $\beta 1-/$ - cardiomyocytes. Actually, these cells display features of early-pacemaker-like cells [see (Fässler et al., 1996)] and predominantly co-express $\mathrm{C} \times 40$ and $\mathrm{C} x 43$. Moreover, we demonstrate a parallel up-regulation of three cardiac connexins in differentiating cardiomyocytes, while in the adult myocardium connexins are regulated by distinct signalling pathways. Thus, an up regulation of connexins in $\beta 1 /-$ cells may affect the terminal differentiation pathways of cardiomyocytes.

Alternatively, the observed effects may result from impaired adhesion of $\beta 1$-/- cardiomyocytes resulting in decreased intracellular tension, which mimics a state of hypotension. Haemodynamic load is an important regulator of early cardiogenesis. $\beta 1-/$ - cardiomyocytes are characterised by high beating frequencies and disarranged sarcomeres (Guan et al., 2001), structures dependent on mechanical stretch. Loss of integrin-dependent adhesion may direct cardiomyocytes towards compensatory activation of signalling pathways that up-regulate connexin expression. This may lead to enhanced intercellular conductance, increased contraction frequency and mechanical load. Indeed, hypertension induced a down-regulation of Cx43 levels in rat aortic cells (Haefliger et al., 1999).

In conclusion, we demonstrate a correlation between integrin function and connexin expression during early cardiomyocyte differentiation dependent on the coordinated action of at least two signalling systems, a direct Rho-dependent integrin signalling at early cardiac differentiation stages and $\beta$-catenin-dependent pathways at advanced stages.

\section{Materials and Methods}

\section{Cell culture and the differentiation of embryoid bodies}

ES cells of line D3 (wild type, wt) (Doetschman et al., 1985) and $\beta 1$ integrin-deficient ( $\beta 1-/-)$ ES cells generated from D3 cells (Fässler et al., 1996) were cultured according to established protocols (Wobus et al., 2002). Because $\beta 1 /$ - cells adhere poorly to feeder cells, they were cultivated without feeder cells in medium supplemented by $5 \mathrm{ng} / \mathrm{ml}$ of recombinant human leukaemia inhibitory factor (LIF; see (Fässler et al., 1996). For differentiation into cardiomyocytes, wt and $\beta 1$-/- cells were cultivated as embryoid bodies (EBs) in hanging drops for 2 and in suspension for 3 days as described (Wobus et al., 2002). At day 5, wt and $\beta 1-/$ - EBs were plated onto $6 \mathrm{~cm}$ gelatin-coated tissue culture dishes (Falcon) for RT-PCR analysis and Western blotting and immunofluorescence analysis of isolated cardiac clusters (Guan et al., 2001). Lithium (LiCl; 5 and $10 \mathrm{mM}$, Sigma), ExoC3 (10 $\mu \mathrm{g} / \mathrm{ml}$ in PBS, $30 \mathrm{~min}$., List Lab., USA), oligopeptides containing RGD $(500 \mu \mathrm{g} / \mathrm{ml}$, H-Gly-Arg-Gly-AspSer-Pro-OH, GRGDSP) and RGE sequences ( $500 \mu \mathrm{g} / \mathrm{ml}$, H-Gly-Arg-GluSer-Pro-OH, GRGESP, Bachem Biochemica GmbH, Heidelberg, Germany), respectively, were added to the culture medium at time points indicated in the result section.

\section{Detection of cardiac-specific connexin mRNA levels}

For semi-quantitative RT-PCR analysis, total RNA was isolated from EB outgrowths by the single step extraction method (Chomczynski and Sacchi, 1987). Connexin mRNA levels of cardiac clusters $(n=10)$ isolated from EB outgrowths at various differentiation stages were analyzed using the Dynalbeads mRNA DIRECT micro kit (Dynal, Oslo, Norway) following the manufacturer's instructions. mRNA was reverse transcribed using polyT tail primer Oligo d(T)16 (Perkin Elmer, Überlingen, Germany) or Dynalbeads Oligo d(T)25 (Dynal, Oslo, Norway) and cDNA was amplified using oligonucleotide primers complementary and identical to the following genes (primer sequences are given in the order antisense, sense-primer and length of the amplified fragment):

Cx40: 5'-CCACGGAGAAGAATGTCTTCA-3' and

5'-TGCTGCTGGCCTTACTAAGG-3' (147 bp);

Cx43: 5'-TGGGGGAAAGGCGTGAG-3' and

5'-CTGCTGGCTCTGCTGGAAGGT-3' (1.3 kb);

Cx45: 5'-ATCATCCTGGTTGCAACTCC-3' and

5'-CTCTTCATGGTCCTCTTCCG-3' (Oyamada et al., 1996),

$\beta$ - tubulin: 5'-GGAACATAGCCGTAAACTGC-3' and

5'-TCACTGTGCCTGAACTTACC-3' (Rohwedel et al., 1998);

MLC-2v: 5'-TGTGGGTCACCTGAGGCTGTGGTTCAG-3' and

5'-GAAGGCTGACTATGTCCGGAGATGC-3' (Lee et al,, 1992). The reverse transcription (RT) reaction and multiplex PCRs for semi-quantitative analyses of RT-PCR products were performed in relation to the expression of the housekeeping gene $\beta$-tubulin or the cardiac-specific gene MLC-2v according to published protocols (Wobus et al., 2002). Fluorescence signals were stored by the E.A.S.Y system (Herolab GmbH, Wiesloch, Germany) and analyzed by Tina 2.08 software (Raytest Isotopenmessgeraete $\mathrm{GmbH}$, Straubenhardt, Germany).

\section{Immunofluorescence assays}

For immunofluorescence analysis, beating cardiomyocyte clusters were isolated from EB outgrowths by a modified procedure of Isenberg and Klöckner (Isenberg and Klöckner, 1982). Isolated cardiac clusters were plated onto gelatin-coated tissue culture plates containing cover slips and cultured in differentiation medium. For immunostaining at various differentiation stages (Guan et al., 2001) cells were rinsed twice with PBS, fixed with methanol: acetone $(7: 3)$ at $-20^{\circ} \mathrm{C}$ for 10 minutes and labelled by the following primary antibodies: mouse anti-titin IgG1 (Z-disk specific epitope, clone T12), mouse anti-Cx43 IgM (Sigma) rabbit antimouse $\mathrm{C} \times 40$ (Chemicon), mouse anti- $\beta$-catenin IgG2b (Alexis Corp. Lausen, Switzerland), mouse anti- $\gamma$-catenin IgG2b (Research Diagnostic Inc., Flanders, NJ, USA), mouse anti pan-cadherin IgG1(Sigma), mouse anti-TCF-4 IgG2a (Upstate, VA, USA) and rabbit anti- $\alpha$-actinin IgG (Sigma). As secondary antibodies, AMCA (aminomethylcoumarin)- 
conjucated goat anti-mouse IgG, DTAF (dichlorotriazinyl amino-fluorescein)-conjugated goat anti-rabbit IgG, Cy3-conjugated goat anti-mouse IgM, Cy3- conjugated goat anti-mouse IgG2a, DTAF-conjugated goat anti-mouse IgG1, Cy3-conjugated goat anti-rabbit IgG (all from Dianova) and AlexaFluor350-conjugated goat anti-mouse IgG1 and AlexaFluor488conjugated goat anti-mouse IgG2b were used. Where indicated specimens were counterstained with $0.5 \mu \mathrm{g} / \mathrm{ml}$ bis-benzimide (Hoechst 33342 ) to visualise the nuclei. After washing, cells were embedded in Vectashield mounting medium (Vector Laboratories, Inc., USA) and analyzed with the fluorescence (Optiphot-2, Nikon) or the confocal laser scanning microscope LSM-510 META (Carl Zeiss, Jena, Germany). For semi-quantitative analysis, clusters of cardiac cells between 50 and $100 \mu \mathrm{m}$ in diameter were analysed for the presence of punctuate gap junctional fluorescence at cell-cell interfaces.

\section{Immunoblotting}

EB outgrowths were washed twice with ice-cold PBS, mechanically transferred into PBS and centrifuged at $1000 \mathrm{rpm}$ for 5 minutes. Cell pellets were re-suspended in hypotonic buffer ( $20 \mathrm{mM}$ Tris, $\mathrm{pH} 7.5 ; 25 \mathrm{mM}$ sodium fluoride; $1 \mathrm{mM}$ EDTA) containing a protease inhibitor mixture tablet (Roche, Molecular Biochemicals) and homogenised in a Dounce homogenizer on ice for $20 \mathrm{~min}$, followed by ultracentrifugation at 80,000 $\mathrm{g}$ for 30 minutes at $4^{\circ} \mathrm{C}$ and the supernatant comprising the cytoplasmic cell fraction was collected (Chen etal, 2000). Protein levels of cytoplasmic $\beta$-catenin were detected using immunoblotting analyses as described (Schmidt et al., 2001). The mouse anti-actin IgG (Clone C4, Chemicon) was used as internal standard.

\section{Acknowledgements}

The skilful technical assistance of Mrs. S. Sommerfeld, K. Meier, O. Weik, Thea Tölle and Mr. B. Claus is gratefully acknowledged. We especially thank Drs. R. Fässler, Max-Planck-Institute of Biochemistry, Martinsried, Germany, for supplying $\beta 1-1-$ ES cells and D. Fürst, Department of Cell Biology, University of Potsdam, Germany, for providing $\alpha$ actinin- and titin-specific antibodies. The results were obtained with financial support by the Deutsche Forschungsgemeinschaft (WO 503/2-1) and Fonds der Chemischen Industrie (FCI), Germany, to A.M.W.

\section{References}

AI, Z., FISCHER, A., SPRAY, D.C., BROWN, A.M. and FISHMAN, G.I. (2000). Wnt1 regulation of connexin43 in cardiac myocytes. J. Clin. Invest 105: 161-171.

BARKER, N., MORIN, P.J. and CLEVERS, H. (2000). The Yin-Yang of TCF/betacatenin signaling. Adv. Cancer Res. 77: 1-24.

BEN ZE'EV, A., SHTUTMAN, M. and ZHURINSKY, J. (2000). The integration of cell adhesion with gene expression: the role of beta- catenin. Exp. Cel/Res. 261:75-82.

CHEN, R.H., DING, W.V. and MCCORMICK, F. (2000). Wnt signaling to beta-catenin involves two interactive components. Glycogen synthase kinase-3beta inhibition and activation of protein kinase C. J. Biol Chem. 275: 17894-17899.

CHOMCZYNSKI, P. and SACCHI, N. (1987). Single-step method of RNA isolation by acid guanidinium thiocyanate- phenol-chloroform extraction. Anal. Biochem. 162 156-159.

CZYZ, J., IRMER, U., SCHULZ, G., MINDERMANN, A. and HULSER, D.F. (2000) Gap-junctional coupling measured by flow cytometry. Exp. Cell Res. 255: 40-46.

DOETSCHMAN, T.C., EISTETTER, H., KATZ, M., SCHMIDT, W. and KEMLER, R. (1985). The in vitro development of blastocyst-derived embryonic stem cell lines: formation of visceral yolk sac, blood islands and myocardium. J. Embryol. Exp. Morphol. 87: 27-45.

ELFGANG, C., ECKERT, R., LICHTENBERG-FRATE, H., BUTTERWECK, A., TRAUB, O., KLEIN, R.A., HULSER, D.F. and WILLECKE, K. (1995). Specific permeability and selective formation of gap junction channels in connexin-transfected HeLa cells. J. Cell Biol 129: 805-817.

FÄSSLER, R., ROHWEDEL, J., MALTSEV, V., BLOCH, W., LENTINI, S., GUAN, K., GULLBERG, D., HESCHELER, J., ADDICKS, K. and WOBUS, A.M. (1996). Differentiation and integrity of cardiac muscle cells are impaired in the absence of beta 1 integrin. J. Cell Sci. 109: 2989-2999.
FERREIRA-CORNWELL, M.C., LUO, Y., NARULA, N., LENOX, J.M., LIEBERMAN, M. and RADICE, G.L. (2002). Remodeling the intercalated disc leads to cardiomyopathy in mice misexpressing cadherins in the heart. J. Cel/ Sci. 115: 1623-1634. FORBES, M.S. and SPERELAKIS, N. (1985). Intercalated discs of mammalian heart: a review of structure and function. Tissue Cell 17: 605-648.

GROS, D.B. and JONGSMA, H.J. (1996). Connexins in mammalian heart function. Bioessays 18: 719-730.

FUKATA M., KURODA S., NAKAGAWA M., KAWAJIRI A., ITOH N., SHOI I, MATSUURA Y., YONEHARA S., FUJISAWA H, KIKUCHI A., KAIBUCHI K. (1999). Cdc42 and Rac1 regulate the interaction of IQGAP1 with beta-catenin. J Biol. Chem. 274: 26044-50.

GUAN, K., CZYZ, J., FURST, D.O. and WOBUS, A.M. (2001). Expression and cellular distribution of alpha(v)integrins in beta(1)integrin-deficient embryonic stem cellderived cardiac cells. J. Mol. Cell Cardiol. 33: 521-532.

HAEFLIGER, J.A., MEDA, P., FORMENTON, A., WIESEL, P., ZANCHI, A., BRUNNER, H.R., NICOD, P. and HAYOZ, D. (1999). Aortic connexin43 is decreased during hypertension induced by inhibition of nitric oxide synthase. Arterioscler. Thromb. Vasc. Biol. 19: 1615-1622.

HERTIG, C.M., BUTZ, S., KOCH, S., EPPENBERGER-EBERHARDT, M., KEMLER, R. and EPPENBERGER, H.M. (1996). N-cadherin in adult rat cardiomyocytes in culture. II. Spatio-temporal appearance of proteins involved in cell-cell contact and communication. Formation of two distinct $\mathrm{N}$-cadherin/catenin complexes. J. Cell Sci. 109 (Pt 1): 11-20.

HYNES, R.O. (1992). Integrins: versatility, modulation and signaling in cell adhesion. Cell 69: 11-25.

ISENBERG, G. and KLOCKNER, U. (1982). Calcium tolerant ventricular myocytes prepared by preincubation in a «KB medium». Pflugers Arch. 395: 6-18.

KANTER, H.L., LAING, J.G., BEAU, S.L., BEYER, E.C. and SAFFITZ, J.E. (1993). Distinct patterns of connexin expression in canine Purkinje fibers and ventricular muscle. Circ. Res. 72: 1124-1131.

KIRCHHOFF, S., KIM, J.S., HAGENDORFF, A., THONNISSEN, E., KRUGER, O. LAMERS, W.H. and WILLECKE, K. (2000). Abnormal cardiac conduction and morphogenesis in connexin40 and connexin43 double-deficient mice. Circ. Res. 87: 399-405.

LEE, K.J., ROSS, R.S., ROCKMAN, H.A., HARRIS, A.N., O'BRIEN, T.X., VAN BILSEN, M., SHUBEITA, H.E., KANDOLF, R., BREM, G., PRICE, J. and. (1992) Myosin light chain-2 luciferase transgenic mice reveal distinct regulatory programs for cardiac and skeletal muscle-specific expression of a single contractile protein gene. J. Biol Chem. 267: 15875-15885.

MAEDA O., USAMI N., KONDO M., TAKAHASHI M., GOTO H., SHIMOKATA K, KUSUGAMI K., SEKIDO Y. (2004). Plakoglobin (gamma-catenin) has TCF/LEF family-dependent transcriptional activity in beta-catenin-deficient cell line. Oncogene 23: 964-72.

NOVAK A., HSU S.C., LEUNG-HAGESTEIJN C., RADEVA G., PAPKOFF J., MONTESANO R., ROSKELLEY C., GROSSCHEDL R., DEDHAR S. (1998). Cell adhesion and the integrin-linked kinase regulate the LEF-1 and beta-catenin signaling pathways. Proc. Natl. Acad. Sci. USA 95: 4374-9.

OYAMADA, Y., KOMATSU, K., KIMURA, H., MORI, M. and OYAMADA, M. (1996). Differential regulation of gap junction protein (connexin) genes during cardiomyocytic differentiation of mouse embryonic stem cells in vitro. Exp. Cel/Res. 229:318-326.

POSTMA, F.R., HENGEVELD, T., ALBLAS, J., GIEPMANS, B.N., ZONDAG, G.C. JALINK, K. and MOOLENAAR, W.H. (1998). Acute loss of cell-cell communication caused by $\mathrm{G}$ protein-coupled receptors: a critical role for c-Src. J. Cell Biol. 140: 1199-1209.

REAUME, A.G., DE SOUSA, P.A., KULKARNI, S., LANGILLE, B.L., ZHU, D., DAVIES, T.C., JUNEJA, S.C., KIDDER, G.M. and ROSSANT, J. (1995). Cardiac malformation in neonatal mice lacking connexin43. Science 267: 1831-1834.

ROHWEDEL, J., GUAN, K., ZUSCHRATTER, W., JIN, S., AHNERT-HILGER, G. FURST, D., FÄSSLER, R. and WOBUS, A.M. (1998). Loss of beta1 integrin function results in a retardation of myogenic, but an acceleration of neuronal, differentiation of embryonic stem cells in vitro. Dev. Biol. 201: 167-184.

ROSS, R.S. and BORG, T.K. (2001). Integrins and the myocardium. Circ. Res. 88: 1112-1119.

ROUACH, N., AVIGNONE, E., MEME, W., KOULAKOFF, A., VENANCE, L., BLOMSTRAND, F. and GIAUME, C. (2002). Gap junctions and connexin expression in the normal and pathological central nervous system. Biol. Cel/94:457-475. 
SCHMIDT, M.M., GUAN, K. and WOBUS, A.M. (2001). Lithium influences differentiation and tissue-specific gene expression of mouse embryonic stem (ES) cells in vitro. Int. J. Dev. Biol 45: 421-429.

STAMBOLIC, V., RUEL, L. and WOODGETT, J.R. (1996). Lithium inhibits glycogen synthase kinase-3 activity and mimics wingless signalling in intact cells. Curr. Biol 6: 1664-1668.

VAN AELST, L. and D'SOUZA-SCHOREY, C. (1997). Rho GTPases and signaling networks. Genes Dev. 11: 2295-2322.

VANDERHEYDEN, M.A., ROOK, M.B., HERMANS, M.M., RIJKSEN, G., BOONSTRA, J., DEFIZE, L.H. and DESTREE, O.H. (1998). Identification of connexin43 as a functional target for Wnt signalling. J. Cell Sci. 111: 1741-1749.

VAN VEEN, A.A., VAN RIJEN, H.V. and OPTHOF, T. (2001). Cardiac gap junction channels: modulation of expression and channel properties. Cardiovasc. Res. 51 : 217-229.

VERHEULE, S., VAN BATENBURG, C.A., COENJAERTS, F.E., KIRCHHOFF, S., WILLECKE, K. and JONGSMA, H.J. (1999). Cardiac conduction abnormalities in mice lacking the gap junction protein connexin40. J. Cardiovasc. Electrophysiol. 10: $1380-1389$.
WEI, L., IMANAKA-YOSHIDA, K., WANG, L., ZHAN, S., SCHNEIDER, M.D., DEMAYO, F.J. and SCHWARTZ, R.J. (2002). Inhibition of Rho family GTPases by Rho GDP dissociation inhibitor disrupts cardiac morphogenesis and inhibits cardiomyocyte proliferation. Development 129: 1705-1714.

WOBUS, A.M., GUAN, K., YANG, H.-T. and BOHELER, K. (2002). Embryonic stem cells as a model to study cardiac, skeletal muscle and vascular smooth muscle cell differentiation. In Methods in Molecular Biology, vol. 185: Embryonic Stem Cells: Methods and Protocols. K.Turksen (Ed.). Humana Press Inc., Totowa, NJ. 127157

WODARZ, A. and NUSSE, R. (1998). Mechanisms of Wnt signaling in development. Annu. Rev. Cell Dev. Biol. 14: 59-88.

YA, J., ERDTSIECK-ERNSTE, E.B., DE BOER, P.A., VAN KEMPEN, M.J., JONGSMA H., GROS, D., MOORMAN, A.F. and LAMERS, W.H. (1998). Heart defects in connexin43-deficient mice. Circ. Res. 82: 360-366.

Received: May 2004 Reviewed by Referees: August 2004 Modified by Authors and Accepted for Publication: January 2005 